\title{
Cord Blood Vitamin D Level in Neonates of Preeclamptic Mothers
}

\author{
- Didem Arman, ${ }^{1}$ (1) Seçil Erçin, ${ }^{2}$ (1) Sevilay Topcuoğlu, \\ (D) Ayşem Kaya, ${ }^{3}$ (1) Fahri Ovalı, ${ }^{4}$ (1) Güner Karatekin ${ }^{1}$
}

\begin{abstract}
'Department of Pediatrics, Division of Neonatology, University of Health Sciences Zeynep Kamil Maternity and Children's Training and Research Hospital, İstanbul, Turkey 2Department of Pediatrics, Division of Neonatology, American Hospital, İstanbul, Turkey ${ }^{3}$ Department of Biochemistry, Institute of Cardiology, İstanbul University, İstanbul, Turkey ${ }^{4}$ Department of Pediatrics, Neonatal Intensive Care Unit, İstanbul Medeniyet University Göztepe Training and Research Hospita İstanbul, Turkey

Submitted: 18.10.2018 Accepted: 14.01.2019
\end{abstract}

Correspondence: Didem Arman, Zeynep Kamil Eğitim ve Araştırma Hastanesi, Pediatri, Yenidoğan Yoğun Bakım Kliniği, İstanbul, Turkey E-mail:dr_didemcaktir@yahoo.com

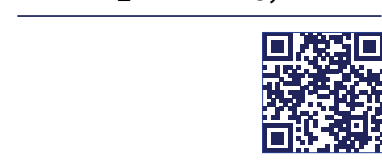

Keywords: Cord blood; preeclampsia; vitamin D.

\section{ABSTRACT}

Objective: Vitamin $D$ deficiency may play a role in the pathogenesis of preeclampsia by causing abnormal placental implantation and by affecting the inflammatory response. The aim of this study was to compare the cord blood vitamin D level in neonates born to preeclamptic mothers with that of a control group of newborns whose mothers were not preeclamptic.

Methods: The preeclamptic group was made up of newborns of mothers classified as having moderate to severe preeclampsia. Neonates of a similar gestational age and birth weight born to normotensive mothers comprised the control group. The cord blood vitamin D level of both groups of newborns was measured and the results were statistically compared.

Results: Sixty neonates born to preeclamptic mothers and 47 born to normotensive mothers were included in the study. The mean serum vitamin $D$ level of the study group was $12.62 \pm 5.43 \mathrm{ng} / \mathrm{mL}$ and $12.85 \pm 5.56 \mathrm{ng} / \mathrm{mL}$ in the control group. The percentage of those determined to have a serum vitamin $D$ level $<20 \mathrm{ng} / \mathrm{mL}$ in the study and the control groups was $89.5 \%$ and $88.9 \%$, respectively. The serum magnesium level in the study group was statistically greater than that observed in the control group $(p<0.00 \mathrm{I})$.

Conclusion: The cord blood vitamin $\mathrm{D}$ level of those born to preeclamptic mothers was not found to be statistically different when compared with the vitamin $D$ level of neonates of normotensive mothers.

\section{INTRODUCTION}

Preeclampsia is a pregnancy-specific disease characterized by hypertension and proteinuria that typically begins after the $20^{\text {th }}$ gestational week. ${ }^{[1]}$ Preeclampsia occurs in $5 \%$ to $8 \%$ of all pregnancies and is considered one of the leading causes of fetal growth retardation, neonatal morbidity and mortality, premature birth, and maternal death. ${ }^{[2,3]}$ Primipara pregnancy, twin pregnancy, history of preeclampsia in a previous pregnancy, chronic hypertension, and obesity are important risk factors. ${ }^{[4]}$

Although the etiology and pathogenesis are not fully understood, it is believed that maternal endothelial cell dysfunction and placental malformation play a key role in preeclampsia. ${ }^{[5]}$ In recent years, it has been shown that vitamin $D$ has an effect on endothelial function and adaptive and natural immunosystems, as well as its known effects on calcium and phosphorus metabolism. ${ }^{[6]}$ Vitamin $D$ also plays a role in the expression of genes that affect implantation of an embryo. ${ }^{[7]}$ It is thought that vitamin $\mathrm{D}$ deficiency may cause abnormal placental implantation and increase the risk of preeclampsia by influencing the inflammatory response and immune functions. ${ }^{[8,9]}$ Several studies have examined a linear relationship between vitamin $D$ deficiency and preeclampsia. ${ }^{[10,11]}$

In some epidemiological studies, an association between preeclampsia and a low vitamin D level during pregnancy has suggested that vitamin $\mathrm{D}$ may be an independent risk factor in the pathogenesis of preeclampsia. ${ }^{[12-16]}$ However, the precise mechanisms of an association between vitamin $\mathrm{D}$ level and preeclampsia have not yet been established. 
Studies have shown a strong correlation between the blood vitamin $\mathrm{D}$ level in a mother and the level found in the umbilical cord. While fetal calcium levels are higher than maternal calcium levels during pregnancy, the concentration of vitamin D in umbilical cord blood and maternal vitamin $D$ levels are similar. ${ }^{[16-20]}$ Although many studies have been conducted examining the relationship between maternal preeclampsia and vitamin D level, a limited number of studies have evaluated the vitamin $D$ level in the cord blood of preeclamptic mothers.

The aim of this study was to evaluate the hypothesis that a low vitamin $D$ level and preeclampsia have a linear correlation. A control group of healthy pregnant women was used as a control group for a comparison of the cord blood vitamin D level.

\section{MATERIALS AND METHODS}

The study group consisted of mothers diagnosed with moderate and severe preeclampsia according to the guidelines of the American College of Obstetricians and Gynecologists and their newborns. The control group comprised non-preeclamptic mothers with newborns of similar gestational age and birth weight to the study group. Mothers diagnosed with chronic hypertension before pregnancy, and those with newborns diagnosed with congenital heart disease were not included in the study. Ethics committee approval was obtained for the research. The participating families were informed about the study parameters and they provided written consent.

\section{Collection of blood samples}

Blood samples $(1.5 \mathrm{~mL})$ were drawn from the umbilical cord into gel tubes. The samples were centrifuged at 5000 rpm at $+4^{\circ} \mathrm{C}$ for 5 minutes. The serum was separated and stored at $-30^{\circ} \mathrm{C}$ until the day of the study.

The magnesium content measured in serum samples obtained from the mothers just before birth was recorded for comparison.
Samples drawn to examine the serum vitamin $D$ levels (25-hydroxy vitamin D) were studied using a Liaison analyzer and a DiaSorin kit (DiaSorin S.p.A., Saluggia, Italy) applying the chemiluminescent immunoassay method.

\section{Statistical analysis}

NCSS 2007 and PASS 2008 statistical software (NCSS, LLC, Kaysville, UT, USA USA) were used to perform the statistical analysis. Descriptive statistical methods (mean, $\mathrm{SD}$, median, frequency, ratio, minimum, maximum) were used for intergroup comparisons of quantitative data with normal distribution determined using Student's t-test, and comparisons of parameters with non-normal distribution were performed with the Mann-Whitney $U$ test. One-way analysis of variance testing was used in the comparison of 3 or more groups with normal distribution and Tukey's honest significant difference test was employed to identify an intergroup difference.

The Kruskal-Wallis test was used for the comparison of 3 or more groups without normal distribution and the Mann-Whitney $U$ test was used to identify a significantly different group. Pearson's chi-square test, Fisher's exact test, and a chi-square test with Yates continuity correction were used to compare qualitative data. Spearman's rank correlation analysis was used to assess relationships between the parameters. Significance was established at $\mathrm{p}<0.05$.

\section{RESULTS}

The study group consisted of the newborns of 60 preeclamptic mothers, and 47 newborns from healthy mothers made up the control group. The demographic characteristics of the participants are shown in Table I. There was no significant difference in the demographic characteristics between groups ( $p>0.05$; Table I).

The mean serum concentration of vitamin $D$ in the newborns of preeclamptic mothers was $12.62 \pm 5.43 \mathrm{ng} / \mathrm{mL}$, while it was $12.85 \pm 5.56 \mathrm{ng} / \mathrm{mL}$ in the control group. The vitamin D vitamin level was $<20 \mathrm{ng} / \mathrm{mL}$ in $89.5 \%$ of the

Table I. Demographic characteristics of the groups

\begin{tabular}{|c|c|c|c|c|c|c|c|}
\hline & \multicolumn{3}{|c|}{ Infants of preeclamptic mothers $(n=60)$} & \multicolumn{3}{|c|}{ Control group $(n=47)$} & \multirow[t]{2}{*}{$\mathbf{p}$} \\
\hline & $\mathbf{n}$ & $\%$ & Mean \pm SD & $\mathbf{n}$ & $\%$ & Mean \pm SD & \\
\hline \multicolumn{8}{|l|}{ Gender } \\
\hline Male & 33 & 55.0 & & 28 & 59.6 & & 0.635 \\
\hline Female & 27 & 45.0 & & 19 & 40.4 & & \\
\hline Gestational week at birth & & & $32.79 \pm 2.43$ & & & $33.20 \pm 2.47$ & 0.393 \\
\hline Birthweight (g) & & & $|75| .49 \pm 6 \mid 3.57$ & & & $1950.21 \pm 588.78$ & 0.092 \\
\hline Height $(\mathrm{cm})$ & & & $41.76 \pm 3.29$ & & & $43.00 \pm 3.26$ & 0.054 \\
\hline Head circumference $(\mathrm{cm})$ & & & $29.7 I \pm 2.1 I$ & & & $30.46 \pm 2.10$ & 0.071 \\
\hline $5^{\text {th }} \min A P G A R \leq 5$ & 7 & 11.5 & & 3 & 6.4 & & 0.509 \\
\hline Antenatal steroid use & 26 & 42.6 & & 14 & 29.8 & & 0.171 \\
\hline
\end{tabular}

APGAR: Appearance, Pulse, Grimace, Activity, and Respiration test; SD: Standard deviation. 
Table 2. Vitamin D, calcium, phosphorus, and magnesium levels in the groups

\begin{tabular}{|c|c|c|c|}
\hline & \multicolumn{2}{|r|}{ Groups } & \multirow[t]{3}{*}{$\mathbf{p}$} \\
\hline & Control group $(n=47)$ & Infants of preeclamptic mothers $(n=60)$ & \\
\hline & Mean \pm SD (Median) & Mean \pm SD (Median) & \\
\hline Vitamin D level, (ng/mL) & $12.85 \pm 5.56(12.90)$ & $12.62 \pm 5.43(11.40)$ & 0.842 \\
\hline Calcium (mg/dL) & $8.31 \pm 1.19$ & $8.48 \pm 1.00$ & 0.443 \\
\hline Phosphorus (mg/dL) & $6.04 \pm 1.21$ & $5.82 \pm 1.52$ & 0.433 \\
\hline Magnesium (mg/dL) & $2.03 \pm 0.40(2.00)$ & $2.47 \pm 0.74(2.20)$ & 0.002 \\
\hline
\end{tabular}

Table 3. Comparison of vitamin D level according to group

\begin{tabular}{lccc}
\hline & \multicolumn{2}{c}{ Groups } & $p$ \\
\cline { 2 - 3 } & $\begin{array}{c}\text { Control group } \\
(\mathbf{n}=47)\end{array}$ & $\begin{array}{c}\text { Infants of } \\
\text { preeclamptic } \\
\text { mothers } \\
(\mathbf{n}=60)\end{array}$ \\
\hline $25(\mathrm{OH})$ vitamin & & & \\
$\mathrm{D} \mathrm{level,} \mathrm{n}(\%)$ & $14(31.1)$ & $23(40.4)$ & \\
$<10$ & $26(57.8)$ & $28(49.1)$ & 0.622 \\
$10-20$ & $5(11.1)$ & $6(10.5)$ & \\
$\geq 20$ & &
\end{tabular}

infants of preeclamptic mothers, and $88.9 \%$ of the control group also had a value $<20 \mathrm{ng} / \mathrm{mL}$.

Tables 2 and 3 illustrate a comparison of the vitamin D, calcium, phosphorus, and magnesium levels of the groups.

There was no statistically significant difference between the 2 groups in terms of vitamin D, calcium, or phosphorus level $(p>0.05)$.

There was a statistically significant difference in the magnesium level $(p<0.01)$. In the study group, the magnesium level was significantly higher than that of the control group. There was a statistically significant correlation between preeclampsia in mothers and the magnesium value in the infant $(r=0.355 ; p=0.012)$.

\section{DISCUSSION}

Contrary to some publications that have reported a lower vitamin $D$ level in the newborns of preeclamptic mothers compared with normotensive mothers, we found no significant difference in the cord blood vitamin $D$ level of preeclamptic and normotensive mothers. The level of vitamin D deficiency and insufficiency was comparable in the 2 groups, and severe deficiency was observed in several cases. The postnatal $24^{\text {th }}$ hour calcium and phosphorus level of the newborns of preeclamptic mothers were similar. There was no significant difference in the development of hypocalcemia at a level requiring calcium replacement.
It has been reported in the literature that vitamin $D$ may be an independent risk factor in the pathogenesis of preeclampsia. Many studies have been performed related to a hypothesis suggesting a relationship between vitamin $D$ and preeclampsia. In a study examining a relationship between vitamin $\mathrm{D}$ deficiency and preeclampsia performed with 32 mothers with an established diagnosis of preeclampsia, it was demonstrated that every I standard deviation increase in vitamin $D$ level during the $24^{\text {th }}$ to $26^{\text {th }}$ gestational weeks may lead to a $30 \%$ reduction in the risk of developing preeclampsia. Halhali et al. ${ }^{[21]}$ analyzed the maternal serum and cord blood level of $1.25 \mathrm{OH}$ vitamin D2 and found lower levels in infants born to preeclamptic mothers.

Several studies have supported the finding that vitamin D levels are significantly lower in the infants of preeclamptic mothers and that maternal blood and umbilical cord blood vitamin D values were correlated. ${ }^{[22-24]}$ In our study, no significant difference was observed between the cord blood vitamin $D$ level of the infants of preeclamptic and normotensive mothers.

Our findings related to analysis of the presence of minerals associated with vitamin $D$ metabolism revealed no significant difference in the calcium or phosphorus level when comparing the neonates of preeclamptic and normotensive mothers; however, the magnesium level was significantly higher in the preeclamptic group.

The results also revealed a statistically significant correlation between the serum magnesium value in preeclamptic mothers and their infants. This is thought to be due to the fact that the mothers in the study group received magnesium treatment due to preeclampsia. These findings are consistent with findings published in the literature. ${ }^{[25,26]}$

Vitamin $D$ deficiency is a common public health problem in our country. One study conducted in western Turkey found that the mean vitamin $D$ value in pregnant women and in cord blood was II.5 $\pm 5.4 \mathrm{ng} / \mathrm{mL}$ and II.5 $\pm 6.8 \mathrm{ng} /$ $\mathrm{mL}$, respectively. ${ }^{[16]}$ The analysis and comparison of cord blood samples in the present study yielded a similar finding (mean: $12.72 \pm 5.46 \mathrm{ng} / \mathrm{mL}$ ). The prevalence of severe deficiencies in our study groups may have prevented the emergence of a difference between the 2 groups. Further studies with a larger number of cases may provide additional meaningful results. 
The prospective design of our study, the selection of newborns of similar gestational age and weight for the control and the study groups, and the relatively large number of patients enrolled in comparison with some previous studies constitute the strengths of our study.

In conclusion, our study did not indicate any significant difference in the vitamin $D$ level measured in the newborns of preeclamptic and normotensive mothers.

Ethics Committee Approval

Approved by the local ethics committee.

Peer-review

Internally peer-reviewed.

Authorship Contributions

Concept: G.K.; Design: G.K., D.A.; Supervision: G.K., F.O.; Fundings: A.K.; Materials: S.T., S.E.; Data: S.E., D.A.; Analysis: D.A., S.T.; Literature search: D.A.; Writing: D.A.; Critical revision: G.K., F.O.

Conflict of Interest

None declared.

\section{REFERENCES}

1. Williams DJ, de Swiet M. The pathophysiology of pre-eclampsia. Intensive Care Med 1997;23:620-9. [CrossRef]

2. Buhimschi IA, Saade GR, Chwalisz K, Garfield RE. The nitric oxide pathway in pre-eclampsia: pathophysiological implications. Hum Reprod Update 1998;4:25-42. [CrossRef]

3. Landy HJ. The impact of maternal illness of the neonate. In: MacDonald MG, Seshia MMK, Mullett MD, editors. Avery's Neonatology. 6th edition. Philadelphia: Lippincott Williams and Wilkins; 2005. p. 205-7.

4. Hernández-Díaz S, Toh $S$, Cnattingius $S$. Risk of pre-eclampsia in first and subsequent pregnancies: prospective cohort study. BMJ 2009;338:b2255. [CrossRef]

5. Chambers JC, Fusi L, Malik IS, Haskard DO, De Swiet M, Kooner JS. Association of maternal endothelial dysfunction with preeclampsia. JAMA 2001;285:1607-12. [CrossRef]

6. Caprio M, Mammi C, Rosano GM. Vitamin D: a novel player in endothelial function and dysfunction. Arch Med Sci 2012;8:4-5.

7. Evans KN, Bulmer JN, Kilby MD, Hewison M. Vitamin D and placental-decidual function. J Soc Gynecol Investig 2004;11:263-71.

8. Adams JS, Hewison M. Update in vitamin D. J Clin Endocrinol Metab 2010;95:471-8. [CrossRef]

9. Lapillonne A. Vitamin D deficiency during pregnancy may impair maternal and fetal outcomes. Med Hypotheses 2010;74:71-5. [CrossRef]

10. Bodnar LM, Catov JM, Simhan HN, Holick MF, Powers RW, Roberts JM. Maternal vitamin D deficiency increases the risk of preeclampsia. J Clin Endocrinol Metab 2007;92:3517-22. [CrossRef]

11. Wei SQ, Audibert F, Hidiroglou N, Sarafin K, Julien P, Wu Y, et al. Longitudinal vitamin D status in pregnancy and the risk of preeclampsia. BJOG 2012;119:832-9. [CrossRef]

12. Hyppönen E, Hartikainen AL, Sovio U, Järvelin MR, Pouta A. Does vitamin $\mathrm{D}$ supplementation in infancy reduce the risk of pre-eclampsia? Eur J Clin Nutr 2007;61:1136-9. [CrossRef]

13. Haugen M, Brantsaeter AL, Trogstad L, Alexander J, Roth C, Magnus P, et al. Vitamin D supplementation and reduced risk of preeclampsia in nulliparous women. Epidemiology 2009;20:720-6.

14. Aghajafari F, Nagulesapillai T, Ronksley PE, Tough SC, O'Beirne M, Rabi DM. Association between maternal serum 25-hydroxyvitamin $D$ level and pregnancy and neonatal outcomes: systematic review and meta-analysis of observational studies. BMJ 2013;346:f1169. [CrossRef]

15. Powe CE, Seely EW, Rana S, Bhan I, Ecker J, Karumanchi SA, et al. First trimester vitamin $\mathrm{D}$, vitamin $\mathrm{D}$ binding protein, and subsequent preeclampsia. Hypertension 2010;56:758-63. [CrossRef]

16. Halicioglu O, Aksit S, Koc F, Akman SA, Albudak E, Yaprak I, et al. Vitamin D deficiency in pregnant women and their neonates in spring time in western Turkey. Paediatr Perinat Epidemiol 2012;26:53-60.

17. Yıldız Ö, Çolak AA, Çoker I, Türkon H. Vitamin D correlation between mother and baby during pregnancy in the winter. Turk J Biochem 2012;37;146-9. [CrossRef]

18. Morley R, Carlin JB, Pasco JA, Wark JD. Maternal 25-hydroxyvitamin $\mathrm{D}$ and parathyroid hormone concentrations and offspring birth size. J Clin Endocrinol Metab 2006;91:906-12. [CrossRef]

19. El Koumi MA, Ali YF, Abd El Rahman RN. Impact of maternal vitamin D status during pregnancy on neonatal vitamin D status. Turk J Pediatr 2013;55:371-7.

20. Basile LA, Taylor SN, Wagner CL, Quinones L, Hollis BW. Neonatal vitamin D status at birth at latitude 32 degrees 72 ': evidence of deficiency. J Perinatol 2007;27:568-71. [CrossRef]

21. Halhali A, Tovar AR, Torres N, Bourges H, Garabedian M, Larrea F. Preeclampsia is associated with low circulating levels of insulin-like growth factor I and 1,25-dihydroxyvitamin D in maternal and umbilical cord compartments. J Clin Endocrinol Metab 2000;85:1828-33.

22. Barrett H, McElduff A. Vitamin D and pregnancy: An old problem revisited. Best Pract Res Clin Endocrinol Metab 2010;24:527-39.

23. Weiler H, Fitzpatrick-Wong S, Veitch R, Kovacs H, Schellenberg J, McCloy U, et al. Vitamin D deficiency and whole-body and femur bone mass relative to weight in healthy newborns. CMAJ 2005;172:757-61. [CrossRef]

24. Sachan A, Gupta R, Das V, Agarwal A, Awasthi PK, Bhatia V. High prevalence of vitamin $\mathrm{D}$ deficiency among pregnant women and their newborns in northern India. Am J Clin Nutr 2005;81:1060-4.

25. Boriboonhirunsarn D, Lertbunnaphong T, Suwanwanich M. Correlation of magnesium levels in cord blood and maternal serum among pre-eclamptic pregnant women treated with magnesium sulfate. J Obstet Gynaecol Res 2012;38:247-52. [CrossRef]

26. Borekci B, Gulaboglu M, Gul M. Iodine and magnesium levels in maternal and umbilical cord blood of preeclamptic and normal pregnant women. Biol Trace Elem Res 2009;129:1-8. [CrossRef] 


\section{Preeklamptik Anne Bebeklerinde Kordon Kanı D Vitamini Düzeylerinin Değerlendirilmesi}

Amaç: D vitamini eksikliğinin, preeklampsi patogenezinde enflamatuvar cevap ve immün fonksiyonlar üzerine etki ederek riski arttırdığı düşünülmektedir. Çalışmamızda preeklamptik anne bebeklerinde kord kanı D vitamini düzeylerini kontrol grubuyla karşılaştırmayı amaçladık.

Gereç ve Yöntem: Çalışma ileriye yönelik olarak düzenlendi. Çalışma grubuna orta ve ağır preeklampsi tanısı almış olan preeklamptik annelerin bebekleri alındı. Annesi preeklamptik olmayan, gestasyonel yaş ve ağılıkları çalışma grubu ile benzer özellikte yenidoğanlar kontrol grubu olarak seçildi. Kordon kanı D vitamini düzeyleri bakılarak istatistiksel olarak karşılaşıırıldı.

Bulgular: Çalışmaya 60 preeklamptik anne bebeği ve kontrol grubu olarak 47 normotansif anne bebeği dahil edildi. Preeklamptik anne bebekleri ve kontrol grubundaki bebeklerin ortalama 25 hidroksi D vitamini $(25 \mathrm{OH}$ D) vitamini düzeyleri sırasıyla $12.62 \pm 5.43$ ve $12.85 \pm 5.56$ $\mathrm{ng} / \mathrm{mL}$ olarak bulundu. Çalışma grubunun $\% 89.5$ 'inde $25(\mathrm{OH}) \mathrm{D}$ vitamini düzeyi $<20 \mathrm{ng} / \mathrm{mL}$ iken kontrol grubunda bu oran \% $88.9 \mathrm{idi}$. Her iki grup arasında vitamin $D$, kalsiyum ve fosfor düzeyleri açısından istatistiksel olarak anlamlı farklııı saptanmadı ( $p>0.05)$. Çalışma grubundaki bebeklerin magnezyum değerleri, kontrol grubundakilere göre anlamlı düzeyde yüksekti $(p<0.01)$.

Sonuç: Çalışmamızda preeklamptik anne bebeklerinin kordon kanı $D$ vitamini düzeylerinin normotansif anne bebeklerinin düzeylerine göre herhangi bir farklılık göstermediği saptanmıştır.

Anahtar Sözcükler: D vitamini; kordon kanı; preeklampsi. 